\title{
Money Supply and Velocity of Money in Nigeria: A Test of Polak Model
}

\author{
Ajibola Arewa ${ }^{1}$ \& P. C. Nwakanma ${ }^{2}$ \\ ${ }^{1}$ Accounting and Finance Department, Lagos State University Lagos, Nigeria \\ ${ }^{2}$ Finance and Banking Department, University of Port Harcourt, River State, Nigeria \\ Correspondence: Ajibola Arewa, Accounting and Finance Department, Lagos State University Lagos, Nigeria. \\ E-mail: ajibolaarewa@yahoo.com
}

$\begin{array}{lc}\text { Received: July 5, } 2013 & \text { Accepted: August 5, } 2013 \quad \text { Online Published: November 18, } 2013 \\ \text { doi:10.5539/jms.v3n4p136 } & \text { URL: http://dx.doi.org/10.5539/jms.v3n4p136 }\end{array}$

\begin{abstract}
The study provides an empirical test of the Polak model using annual time series data from Nigeria for a sampling period of 1985 to 2011. The Johansen and Jesulius multivariate cointegration procedures are particularly employed to investigate the long-run relationship between money supply and other selected macro-economic variables; our findings show convincing evidence in support of long-run equilibrium relationship existing in these variables. Also, the Granger Causality Test is employed to examine the causality between money and the selected macroeconomic variables; in all, the findings reveal bidirectional causality between money and core macro-economic variables such as national income, net foreign domestic credit and export in Nigeria. The study also finds that the marginal propensity to import is 20 percent, while the marginal velocity of money in circulation is very high almost approaching 300 percent suggesting that the Nigerian economy is inflationary.
\end{abstract}

Keywords: money, velocity of money, polak model, long-run relationship, granger causality, Nigeria

\section{Introduction}

It is no longer an intuition for one to express a concern regarding the tempo at which money circulates from one hand to another in Nigeria. Year-on year government, corporate institutions and individuals increase their expenditure. Consequence upon this is the usual increase in the stock of money in circulation. However, the speed of this circulation varies over time depending on the supply of money. An increase in money supply has the tendency to raise the tempo (i.e. the velocity) at which money circulates. It was alleged that when the velocity of money raises all other things being equal, the purchasing power declines (i.e. prices of goods and services rise). The opposite occurs when velocity of money decreases. The velocity of money in circulation can induce inflation when it is high or deflation when it is low. Thus, velocity appears to be an important determinant of the value of money in an economy.

The stylized fact behind our discussion so far is that velocity of money in circulation influences other macroeconomic variables either positively or negatively which consequently changes the equilibrium status of an economy. Obviously over the years, several studies such as Emerson (2006), Moosa (1997), Miyao (1996), Moazzami and Gupta (1996), Duck (1993), Karfakis (2002) and Amin (2011) have thoroughly investigated the relationship between the velocity of money in circulation as proxied by inflation and some randomly selected macroeconomic variables using both cross sectional and time series data. In Nigeria, this investigation is carried out to the best of our knowledge by Anoruo (2002), Nwaobi (2002), Nwafor (2007) and Omanukwue (2010). The study of Anoruo examines the stability of money demand function of Nigeria using Johansen and Juselius multivariate cointegration mechanism and documents that there is long-run relationship between money output and real discount rate. Nwa (2002) adopts this technique and finds that long-run relationship exists between money supply, real GDP, inflation and interest rate. The same is true about the study of Nwafor (2011) and they conclude that the supply of money is a strong factor that maintains long-run influence on Nigerian macro-economic activities.

However, our study employs the Polak model (Polak, 1957, 1997a, 1997b and Polak et al., 1971) which simultaneously captures the empirical relationship between/among some macroeconomic variables of which 
money supply is given serious consideration. Thus, we refine the model by adjusting its parameters and introducing stochastic terms into it. This enables us to examine the net effect of money supply on the long-run equilibrium position of Nigerian core macro-economic variables.

The rest of the paper is structured as follows: section 2 discusses literature and the Polak model, section 3 stresses on the modified Polak model which is considered applicable in Nigeria. Section 4 analyses and discusses empirical results, while conclusion and recommendations are presented in section 5 and 6 respectively.

\section{Review of Related Literature}

A considerable number of academic papers have explained the causal effects of money supply or even its velocity of circulation on fluctuations of macroeconomic variables in both transitioned and emerging economies. Without equivocation, the low level of economic growth in some African countries can partly be traced to the failure of the monetary authorities to sustain disciplined monetary policies capable of controlling, mobbing and directing inflows of cash assets in circulation. Thus, uncontrolled inflows of transactions distort significant macroeconomic variables and impair economic growth drastically. Montial (1995) and Emenuga (1996) once assert that the possible effects of money in circulation on growth can manifest in three different channels: increasing the rate of savings in nations; improving the efficiency of financial intermediations and the efficiency of capital stocks. Also, the modern macro-economic theories in relation to money and economic development seem to agree that there is a systematic relationship between money and growth (Bemanke and Blinder, 1992) and (Gbatak, 1995). In the same token, the studies of Mansor (2005), and Owoye and Onafowora (2007); also the early studies such as Greewood and Cagan (1956), Sims (1972) and Wechtel (1995) have found a strong support for a positive relationship between money and growth.

In Nigeria, Omanuhwue (2010) employs the Engle-Granger two-stage cointegration approach to investigate the long-run relationship between money, prices, output and interest rate. He takes ratio of demand deposit to time deposit as a proxy for financial development, and discovers a long-run relationship among the variables which is in tandem with the quantity theory of money; concluding that in an absolute sense, the restrictions imposed by the quantity theory of money on real output and money supply do not hold. Thus, evidence of weak uni-directional causality between money supply and core consumer price index with direction of flow from money supply is established by him. Finally, Nwafor (2011) uses Johansen-Jesulius multivariate cointegration technique in his study and posits that there is existence of long-run aggregate money demand in Nigeria in line with the Keynesian liquidity preference theory. Hence, the author agues that to initiate and sustain a long-run economic growth in Nigeria, stability of money is inevitable.

Thus, previous studies have shown that economic growth is influenced by money and velocity of money in circulation but a concession has not been reached on the intensity and direction of effects relating to this relationship, thereby leaving gap in the literature. We attempt to fill this gap by estimating the polak model to show the nature/direction of long-run relationship between money supply and specified macro-economic variables in the model.

\subsection{The Polak Model}

The existence of relationships between/among monetary variables, BOP items, GDP and other macroeconomic variables was never documented in finance literature; though it might occur slightly in various quarters but nobody gave it a serious consideration until 1957, when a man called J.J Polak decided to reason critically how these variables relate together in simultaneous framework. In a nutshell, Polak (1957) developed a monetary policy model independently which was named after his name, the Polak model in short and since it has been consistently used by the International Monetary Fund (IMF) for policy purpose, therefore it is also known as the IMF monetary model. The model presents intuitive relationships between/among monetary policy, income and balance of payments (BOP) items. The core characteristic of the model is its relative simplicity. The model became popular in the early postwar years for many IMF members; due to its tremendous potentials to explain variations in basic macro-economic variables even in the faces of paucity of data. Another striking element of the model is that it is deeply rooted on the key policy variables which serve as control variables to governments for attaining external equilibrium. Right from inception, Polak (1997a and 1997b) pointed out the needs as well as the possibilities of modifying the model over time to suit the complexity of our modern economies. For instance, the model has been extensive utilized in situations where exchange rate changes become a normal component of the IMF stand-by arrangements. Sen (1999) reviewed the analytical aspects of both the IMF and World Bank approaches to macroeconomic management in the less developed countries (LDCs). Apparently, the IMF approach to macroeconomic management shows itself in the IMF programmes, which represent a conventional response to macroeconomic imbalances of the LDCs. These imbalances manifest themselves as 
followings: BOP deficits, unemployment, inflation and growth. Imbalances are seen to be the end products of excessive demands. These can be resolved through disciplined monetary and fiscal policies which are key elements in the Polak model. The IMF has developed the monetary approach to the BOP after the late 1950s, based on the intuitive simplicity of the Polak model, which is subject to modifications in this our co temporal era Therefore the empirical validity of the model is still reverberating and awaiting fresh insights/innovations in a way to improve its estimated values. Subsequent upon this, our study is motivated to introduce unique parameters into the original equations of J.J Polak so as to estimate the relationships (if any) between the concerned variables in Nigerian emerging economy.

\section{Methodology}

This study utilizes simultaneous equations which were originally estimated by Polak (1957) and Polak et al. (1971). These equations use changes in domestic credit, elements of BOP and monetary variables to analyse changes in GDP and imports. Hence the model is based on the following seven economic variables: Gross Domestic product (Y), import (m), the stock of money (mo), Changes in Net Foreign Assets (CNFA), changes in Net Domestic Credit (CNDC), Exports (x) and Capital movements (CM). The last three variables (X, CM and CNDC) are exogenous. Polak (1957) summarised the relationship among these variables as:

$$
\begin{array}{cc}
M_{t}=m Y_{t} & 0<m<1 \\
Y_{t}=1 / k M O_{t} & 0<k<1 \\
M O_{t}=M O_{t-1}+C N F A_{t}+C N D C_{t} \\
C N F A_{t}=X_{t}+C M_{t}-M_{t}
\end{array}
$$

Equation (1) shows a causal relationship between imports and GDP, while equation (2) represents GDP-money supply relationship. The last two equations are definitional or identities. Thus, it is evident that there is simultaneity involved in the equations as they use endogenous variables as explanatory. The coefficient $\mathrm{m}$ is average and marginal propensity to import, while $1 / \mathrm{k}$ is average and marginal income velocity of money. However in this study, we refine the equations by introducing new parameters and changing them to stochastic specifications as follows:

Combine equations 2 and 3

$$
\begin{gathered}
Y_{t}=1 / k\left(M O_{t-1}+C N F A_{t}+C N D C_{t}\right) \\
Y_{t}=1 / k M O_{t-1}+1 / k C N F A_{t}+1 / k C N D C_{t}
\end{gathered}
$$

Bring in constant and stochastic error terms into equation (6) and changing its parameters as follows:

$$
Y_{t}=\beta_{0}+\beta_{1} M O_{t-1}+\beta_{2} C N F A_{t}+\beta_{3} C N D C_{t}+\mu_{t}
$$

Combine equations (1) and (2)

$$
M O_{t}=k / m M_{t}
$$

Substitute equation 4 into 8

$$
\begin{gathered}
M O_{t}=k / m\left(X_{t}+C M_{t}-C N F A\right) \\
M O_{t}=k / m X_{t}+k / m C M_{t}-k / m C N F A
\end{gathered}
$$

Bring in constant, error term and changing the parameters of equation (10) as follows:

$$
M O_{t}=P_{0}+P_{1} X_{t}+P_{2} C M_{t}-P_{3} C N F A_{t}+e_{t}
$$

Furthermore, to estimate the true values of $\mathrm{m}$ and $1 / \mathrm{k}$ that is average and marginal propensity to import and average and marginal income velocity of money respectively, we remodel equations (1) and (2) as follows.

Restate equations (1) and (2), and bring in constants and error terms

$$
\begin{gathered}
M_{t=m y_{t}} 0<m<1 \\
M_{t}=\alpha_{0}+m y_{t}+w_{t} \\
Y_{t}=1 / k M O_{t} \quad 0<k<i \\
Y_{t}=a_{0}+1 / k M O_{t}+v_{t}
\end{gathered}
$$

The study adopts equations (7), (11), (12) and (13) to estimate the parameters (i.e.) $\beta$ 's and P's), and to estimate the true values of $\mathrm{m}$ and $1 / \mathrm{k}$ (i.e. the margin propensity to import and marginal income velocity of money) and then to examine the long-run equilibrium position of the Nigerian economy. 


\subsection{Data}

Data on nominal income (y) representing the growth level of Nigerian economy, stock of money (MO) representing money supply, changes in net domestic credit (CNDC) which is taken to be a control variable, changes in net foreign asset (CNFA), exports and capital movement for a period of 1985-2011 are sourced from the various volumes of CBN Statistical bulletin.

\section{Empirical Results}

A time series regression results must first be subjected to a unit root test before they can be considered valid or realistic. To achieve this, we employ Dickey Fuller's (1979) unit root test to examine the order of integration of all the variables series included in the models stated in section three. The results of this test are reported in table 1 .

Table 1. Results of the unit root test

\begin{tabular}{llll}
\hline Variable series & Critical value at 5\% & Level & First Difference \\
\hline Y & -196 & $(2.38)^{*}$ & $(-2.11)^{*}$ \\
Mo(-1) & -1.96 & 1.21 & $(2.93)^{*}$ \\
NFA & -1.96 & $(-4.45)^{*}$ & $(-8.43)^{*}$ \\
NDC & -1.96 & -1.71 & $(-3.08)^{*}$ \\
MO & -1.95 & -1.8 & $(-2.33)^{*}$ \\
CM & -1.95 & $(-2.60)^{*}$ & $(-6.46)^{*}$ \\
X & -1.95 & -1.7 & $(-3.94)^{*}$ \\
M & -1.95 & -1.63 & $(-3.34)^{*}$ \\
\hline
\end{tabular}

Note: The nut hypothesis is that series is not stationary. The critical value for rejection of the null hypothesis at $5 \%$ significance level is approximately fixed at -1.95 for model with trend but no intercept, while * denotes rejection of the null hypothesis.

The unit root test depicted in table 1 is conducted under the assumption of trend based on Akaike information criterion at different lag strengths. The test shows that the null hypothesis that there is presence of a unit root is rejected at level for the series of variables such as nominal income (y); net foreign asset (NFA) and capital movement (CM). All these variables series are found to be significantly stationary at 5 percent significance level. However, the test also reveals that using a critical value of 5 percent, all the series of the specified variables are found to be integrated of order one I(1) because the null hypothesis is completely rejected for all of these series at first difference using a critical value of 5 percent. This informs us to examine if these variables maintain a long-run equilibrium relationship in Nigeria.

\subsection{Test of Long-Run Relationship}

The study employs Johansen and Juselius (1990) multivariate co integration mechanism to investigate if there is presence of co integration among the specified variables. The outputs of this test are presented in table $2 \mathrm{a}$ and $2 \mathrm{~b}$ respectively.

Table 2a. Co-integration test results for equation (7)

\begin{tabular}{lllll}
\hline Ho: rank $\mathbf{r} \leq \mathbf{k}$ & Trace statistic & $\begin{array}{l}\text { Critical value } \\
\text { at 5\% }\end{array}$ & Max-Eigen statistic & $\begin{array}{l}\text { Critical value } \\
\text { at 5\% }\end{array}$ \\
\hline $\mathrm{r} \leq 0$ & $(142.60)^{*}$ & 47.86 & $(96.46)^{*}$ & 27.58 \\
$\mathrm{r} \leq 1$ & $(46.14)^{*}$ & 29.8 & $(26.00)^{*}$ & 21.13 \\
$\mathrm{r} \leq 2$ & $(20.14)^{*}$ & 15.49 & $(19.69)^{*}$ & 14.26 \\
$\mathrm{r} \leq 3$ & 0.45 & 3.84 & 0.45 & 3.84 \\
\hline
\end{tabular}


Table 2b. Co-integration test results for equation (11)

\begin{tabular}{lllll}
\hline Ho: rank $\mathbf{r} \leq \mathbf{k}$ & Trace statistic & $\begin{array}{l}\text { Critical value } \\
\text { at 5\% }\end{array}$ & Max-Eigen statistic & $\begin{array}{l}\text { Critical value } \\
\text { at 5\% }\end{array}$ \\
\hline $\mathbf{r} \leq 0$ & $(192.79)^{*}$ & 40.17 & $(108.32)^{*}$ & 24.16 \\
$\mathrm{r} \leq 1$ & $(83.47)^{*}$ & 24.27 & $(61.82)^{*}$ & 17.8 \\
$\mathrm{r} \leq 2$ & $(21.65)^{*}$ & 12.32 & $(21.64)^{*}$ & 11.22 \\
$\mathrm{r} \leq 3$ & 0.004 & 4.13 & 0.004 & 4.13 \\
\hline
\end{tabular}

Notes: $r$ implies the number of co integrated vectors, while * denotes rejection of the null hypothesis at $5 \%$ significance level.

The co integrating test results in tables (2a) and (2b) are exactly analogous. Both indicate that the null hypothesis that there is no presence of long-run relationship is rejected up to the point $r \leq 2$. Thus, the findings reveal that there are atleast three co integrating vectors in the system and as such, we can say that all the specified variables in equation (7) and those in equation (11) have long-run equilibrium relationship. Hence, we can use the information provided by the models to predict the future variation in the growth of Nigerian economy. Furthermore, we verify the intensity of the relationship by analyzing the dynamic properties of the system, we adopt the forecast error variance decomposition (FEVDC) and impulse response function (IRF) which are computed from the moving average (MA) representation of the VECM. In order to have a unique ordering structure, we make the target variable at the first and then the other variables follow. Therefore, the ordering structures employed in this study are: for equation (7), $\mathrm{Y}, \mathrm{MO}_{\mathrm{t}-1} \mathrm{NFA} \& \mathrm{NDC}$ while equation (11), $\mathrm{MO}, \mathrm{CM}, \mathrm{X}$ \& NFA. By introducing a one-period standard deviation shock to one of the endogenous variables, the observable responses of the system to the innovations, that is the size and characteristics of the effects, either positive or negative are presented in table $3 a$ to $b$ and their respective figures, while the breakdown of the variance decomposition attributed to each endogenous variables are shown in table $4 \mathrm{a}$ to $\mathrm{b}$ with corresponding figures.

Table 3a. Results of impulse response functions for variables in equation (7)

\begin{tabular}{lllll}
\hline Period & Y & MO & NFA & NDC \\
\hline 1 & 1138704. & 0.000000 & 0.000000 & 0.000000 \\
2 & 1093020. & 344074.2 & 145611.8 & 37779.33 \\
3 & 1027785. & 835405.6 & 353542.8 & 91727.50 \\
4 & 934631.2 & 1537018. & 650464.2 & 168764.5 \\
5 & 801608.7 & 2538906. & 1074462. & 278771.8 \\
6 & 611655.1 & 3969584. & 1679924. & 435860.2 \\
7 & 340404.9 & 6012566. & 2544511. & 660179.5 \\
8 & -46935.32 & 8929904. & 3779126. & 980503.1 \\
9 & -600049.8 & 13095809 & 5542133. & 1437919. \\
10 & -1389887. & 19044642 & 8059673. & 2091101. \\
\hline
\end{tabular}

Cholesky Ordering: Y, MO, NFA \& NDC.

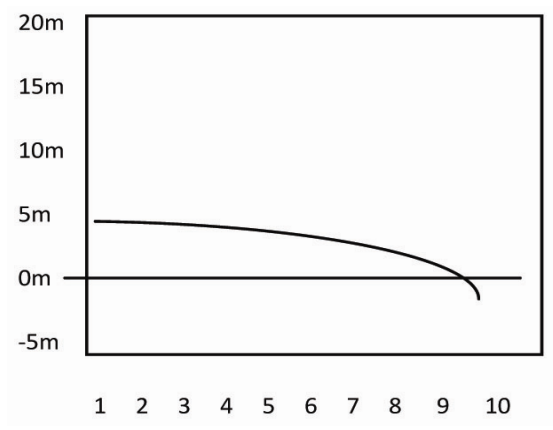

Figure 1. Response of $\mathrm{Y}$ to $\mathrm{y}$ 


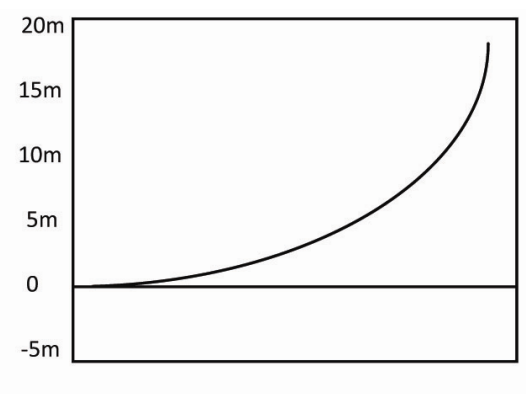

$\begin{array}{llllllllll}1 & 2 & 3 & 4 & 5 & 6 & 7 & 8 & 9 & 10\end{array}$

Figure 2. Response of Y to Mot-1

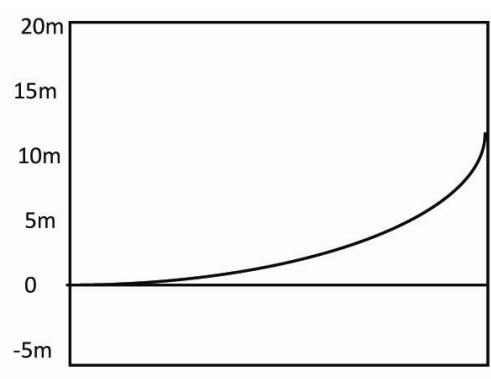

$\begin{array}{llllllllll}1 & 2 & 3 & 4 & 5 & 6 & 7 & 8 & 9 & 10\end{array}$

Figure 3. Response of Y to NFA

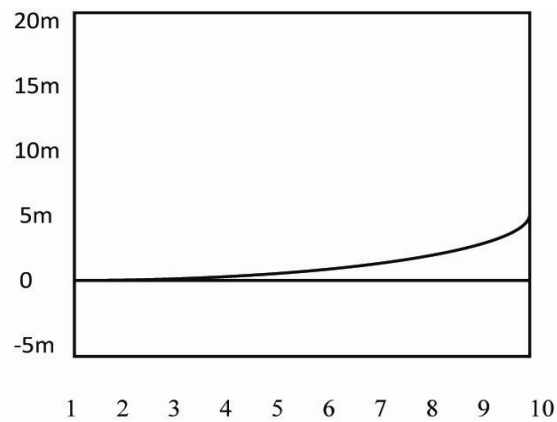

Figure 4. Response of Y to NDC

Table 3b. Results of impulse response functions for variables in equation (11)

\begin{tabular}{lllll}
\hline Period & MO & CM & X & NFA \\
\hline 1 & 2123513. & 0.000000 & 0.000000 & 0.000000 \\
2 & 2260036. & 313053.0 & -79654.85 & 607120.4 \\
3 & 2258198. & 308838.8 & -78582.58 & 598947.7 \\
4 & 2258223. & 308895.6 & -78597.01 & 599057.7 \\
5 & 2258223. & 308894.8 & -78596.82 & 599056.2 \\
6 & 2258223. & 308894.8 & -78596.82 & 599056.2 \\
7 & 2258223. & 308894.8 & -78596.82 & 599056.2 \\
8 & 2258223. & 308894.8 & -78596.82 & 599056.2 \\
9 & 2258223. & 308894.8 & -78596.82 & 599056.2 \\
10 & 2258223. & 308894.8 & -78596.82 & 599056.2 \\
\hline
\end{tabular}

Cholesky Ordering: MO, CM, X \& NFA. 


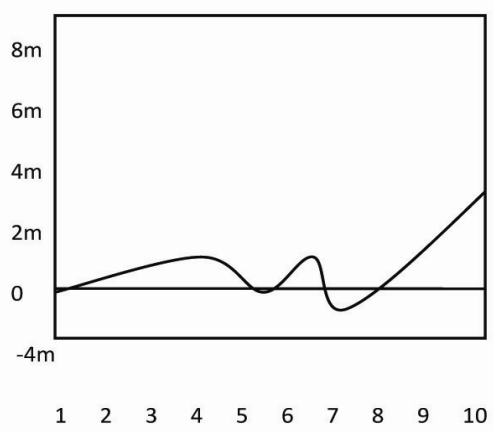

Figure 5. Response of MO to MO

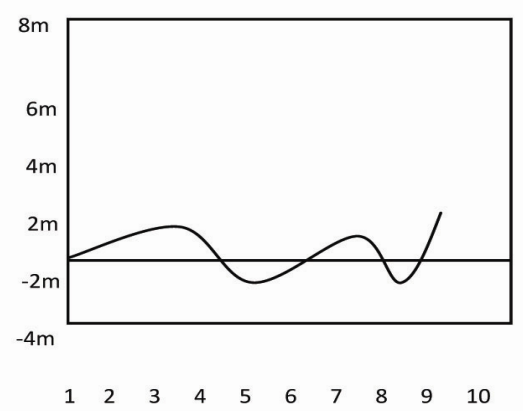

Figure 6. Response of $\mathrm{MO}$ to $\mathrm{CM}$

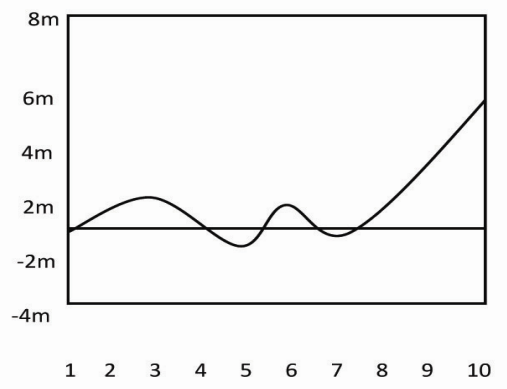

Figure 7. Response of $\mathrm{MO}$ to $\mathrm{X}$ 


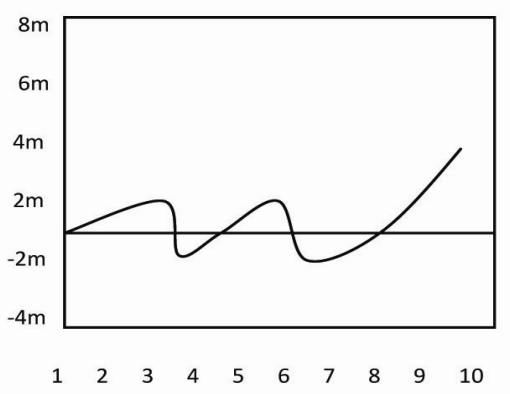

Figure 8. Response of MO to NFA

The impulse response functions (IRFs) analyze the effects of money supply, net foreign asset and net domestic credit on national income as reported in table $3 \mathrm{a}$ and its corresponding figures. For a time horizon of ten periods, money supply, net foreign asset and net domestic credit impact positive effect on national income. The first observation from the IRFs shows that fluctuations in national income decrease over time up to the $7^{\text {th }}$ year and then become negative as shown by the curve that crosses the origin to the horizontal axis in figure (1). The second observation shows that shocks or fluctuations of money supply create positive effect on national income and this effect is found to be persisting for a long time as indicated by the curve that move upward from the horizontal axis in figure (2). Similar results are evident in the third and fourth observations in which shocks of net foreign asset and net domestic credit create prolong positive effects on national income. Also the IRFs results in table 3(b) explain the effects of capital movement, export and net foreign asset on the supply of money. The effects of capital movement and net foreign asset on the supply of money are positive as revealed in the second and fourth observations in table 3(b). However, the effects are found to be inconsistent as revealed by the curves crawling along the lines of origins in figures (6) and (8) respectively. Conversely the effect of export on money supply is negative and does not persist for a long time as shown by the curve moving closer and closer to the horizontal axis in figure 7.

Table 4a. Results of variance decomposition for variables in equation (7)

\begin{tabular}{llllll}
\hline Period & S.E. & Y & MO & NFA & NDC \\
\hline 1 & 1138704. & 100.0000 & 0.000000 & 0.000000 & 0.000000 \\
2 & 1622454. & 94.64293 & 4.497377 & 0.805468 & 0.054221 \\
3 & 2126031. & 78.48841 & 18.05947 & 3.234403 & 0.217725 \\
4 & 2864883. & 53.86768 & 38.72911 & 6.936282 & 0.466919 \\
5 & 4065508. & 30.63701 & 58.23178 & 10.42916 & 0.702044 \\
6 & 5972621. & 15.24413 & 71.15445 & 12.74357 & 0.857840 \\
7 & 8879718. & 7.043545 & 78.03903 & 13.97658 & 0.940841 \\
8 & 13184763 & 3.196077 & 81.26907 & 14.55507 & 0.979782 \\
9 & 19454590 & 1.563105 & 82.63998 & 14.80060 & 0.996310 \\
10 & 28503374 & 0.965957 & 83.14130 & 14.89039 & 1.002354 \\
\hline
\end{tabular}

Cholesky Ordering: Y, MO, NFA \& NDC. 


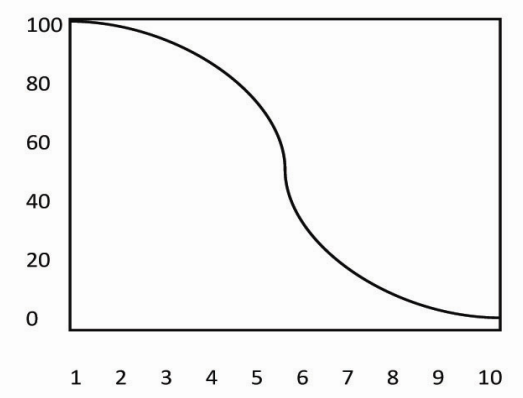

Figure 9. Percent y variance due to y

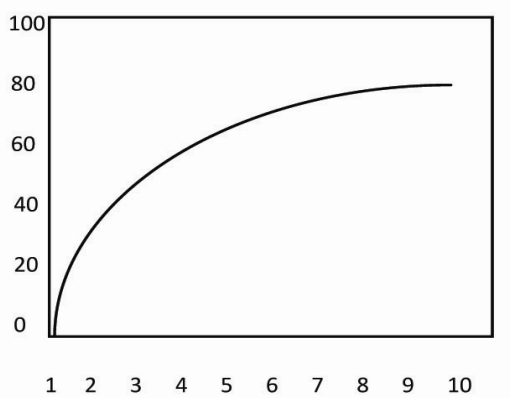

Figure 10. Percent y variance due to Mot-1

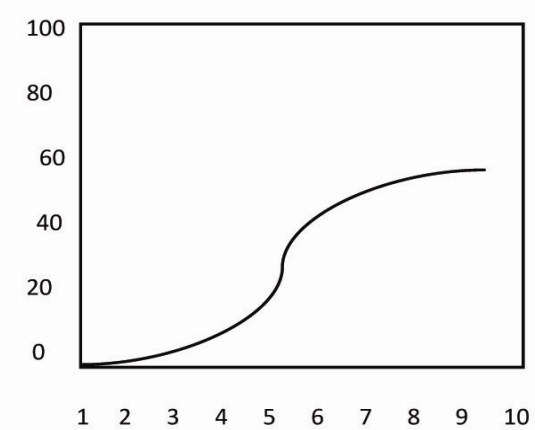

Figure 11. Percent y variance due to NFC 


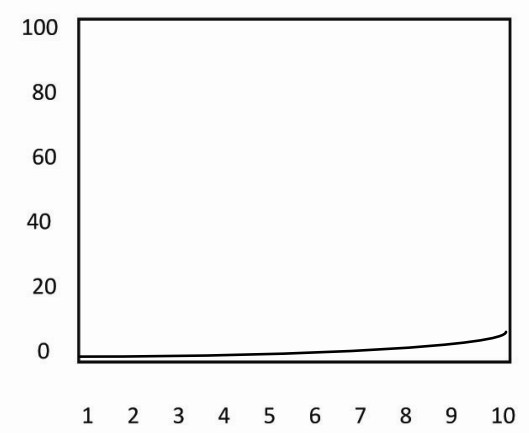

Figure 12. Percent y variance due to NDC

Table $4 \mathrm{~b}$. Results of variance decomposition for variables in equation (11)

\begin{tabular}{llllll}
\hline Period & S.E. & MO & CM & X & NFA \\
\hline 1 & 171291.7 & 100.0000 & 0.000000 & 0.000000 & 0.000000 \\
2 & 439070.0 & 85.17698 & 5.920547 & 1.259486 & 7.642984 \\
3 & 727932.0 & 75.84076 & 5.932325 & 3.322703 & 14.90421 \\
4 & 1166552. & 71.54781 & 9.082732 & 1.311521 & 18.05794 \\
5 & 1250107. & 65.60620 & 10.51963 & 1.150617 & 22.72355 \\
6 & 1442927. & 51.75825 & 8.771929 & 18.98992 & 20.47990 \\
7 & 2675867. & 78.08387 & 4.579702 & 8.169175 & 9.167253 \\
8 & 3838127. & 59.16039 & 10.85524 & 5.427475 & 24.55690 \\
9 & 5554701. & 67.71815 & 12.16930 & 5.693582 & 14.41897 \\
10 & 9530897. & 70.52536 & 4.239538 & 12.80701 & 12.42809 \\
\hline
\end{tabular}

Chosky Ordering: MO, CM, X \& NFA.

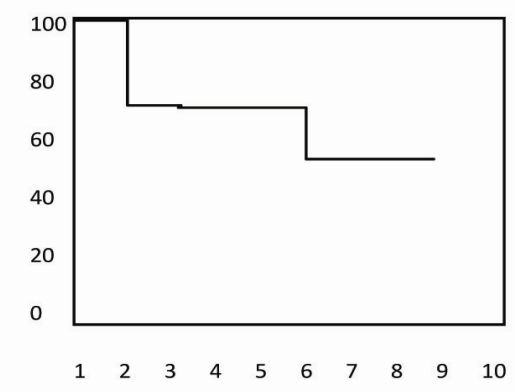

Figure 13. Percent MO variance due to MO 


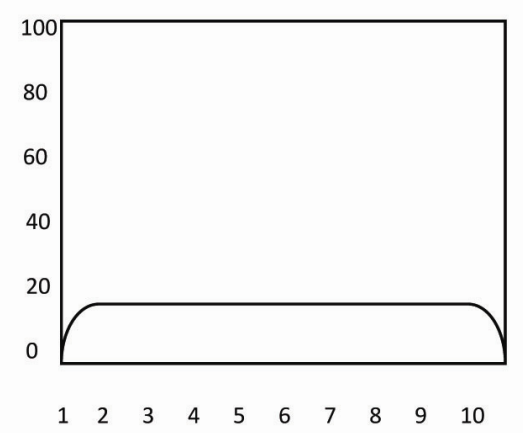

Figure 14. Percent MO variance due to $\mathrm{CM}$

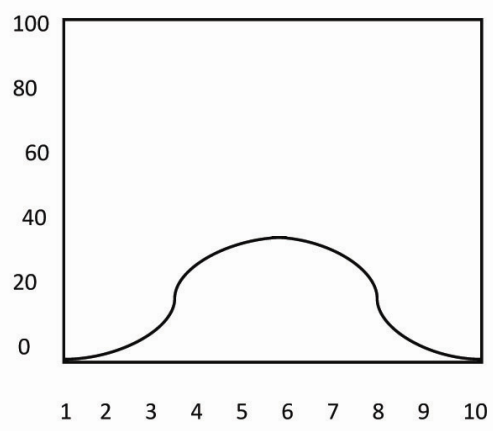

Figure 15. Percent $\mathrm{MO}$ variance due to $\mathrm{X}$

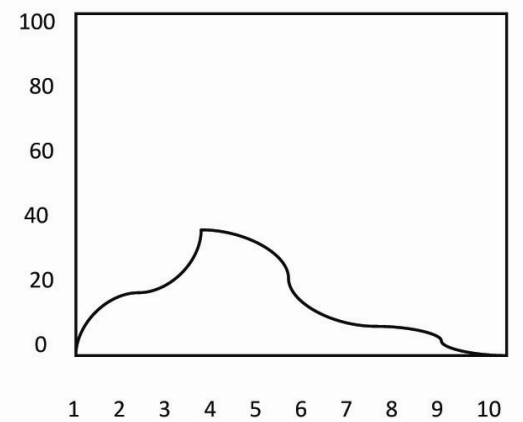

Figure 16. Percent y variance due to NDC

The results of variance decomposition in table 4 (a) show that in the first observation about 100 percent of the forecast error of the Nigerian national income is explained by its own innovation and the fluctuations from its own shock gradually reduced to 9.6 percent after 10 years as shown by the curve that stream down to horizontal axis in figure 9. Meanwhile, instability in money supply, net foreign asset and net domestic credit explains 83.14, 14.89 and 1.00 percents respectively. This reveals to us that money supply is the most volatile factor of all the 
three factors influencing changes in national income. The upward moving curves in figures (10), (11) and (12) show that fluctuations in the shocks of both money supply and net foreign asset increase rapidly, but those of net domestic asset increase very slowly over time. Also, the variance decomposition results in table 4(b) reveal to us that changes in the shocks of capital movement, export and net foreign asset explain about $4.24,12.81 \& 12.43$ percents respectively of the fluctuations in the stock of money in circulation. Fluctuations in export are found to be the most volatile factor to the supply of money. However, the falling and rising curves in figures (14), (15) and (16) show that fluctuations in capital movement, export and net foreign asset are inconsisted over the period of are observation.

Further empirical investigation in this study involves estimating the true values of $m$ (i.e. average and marginal propensity to import and 1/k (i.e. average and marginal velocity of money in circulation). The estimated parameters of equations 12 and 13 reveal these values and are reported in table 5

Table 5. The values of $\mathrm{M}$ and $1 / \mathrm{k}$

\begin{tabular}{lll}
\hline Equation & Coefficient & t-value \\
\hline 12 & 0.21 & 8.76 \\
13 & 2.57 & 8.15 \\
\hline
\end{tabular}

Note: 0.21 and 2.57 are the estimated values of $\mathrm{m}$ and $1 / \mathrm{k}$ respectively.

A quick view of the regression results in table 5 shows that average and marginal propensity to import is 21 percent while the average marginal velocity of money in circulation is about 257 percent. This means that the rate of at which money circulate in Nigeria is very high, at most approaching 300 percent. This is an indication that the country is under the ember of inflation. The rate at which people import in Nigeria is attractively encouraging but the illegal activities of smugglers have made it impossible for the economy to stabilize. We also, discover that increase in national income has a significantly positive impact on importation. Likewise, an increase in money supply leads to upward rise in national income but its inflationary tendency may jeopardize expected growth.

Lastly, we employ the Granger Causality Test to examine the direction of causality between each pair of variables under investigation. The test results are reported in table 6(a) and (b) respectively.

Table 6a. Results of Granger Causality Test for equation (7)

\begin{tabular}{llll}
\hline Null Hypothesis: & Obs & F-Statistic & Prob. \\
\hline MO does not Granger Cause Y & 24 & $(6.23206)^{*}$ & 0.0209 \\
Y does not Granger Cause MO & & $(19.2552)^{*}$ & 0.0003 \\
NFA does not Granger Cause Y & 26 & 1.47994 & 0.2361 \\
Y does not Granger Cause NFA & & $(5.58747)^{*}$ & 0.0269 \\
NDC does not Granger Cause Y & 26 & $(27.9915)^{*}$ & $2.00 \mathrm{E}-05$ \\
Y does not Granger Cause NDC & & $(4.88234)^{*}$ & 0.0374 \\
NFA does not Granger Cause MO & 24 & -0.43246 & 0.5179 \\
MO does not Granger Cause NFA & & $(4.31689)^{*}$ & 0.0502 \\
NDC does not Granger Cause MO & 24 & $(50.6992)^{*}$ & $5.00 \mathrm{E}-07$ \\
MO does not Granger Cause NDC & & $(6.89133)^{*}$ & 0.0158 \\
NDC does not Granger Cause NFA & 26 & -1.04854 & 0.3165 \\
NFA does not Granger Cause NDC & & $(6.59561)^{*}$ & 0.0172 \\
\hline
\end{tabular}

The Test of cause and effect conducted on income, money supply, net foreign asset and net domestic credit reveals that bidirectional causality exist in the relationships between money supply and national income, net domestic credit and national income, net domestic credit and money supply while unidirectional causality is evident in the relationships between net domestic credit and net foreign asset. 
Table 6b. Results of Granger Causality Test for variables in equation (11)

\begin{tabular}{llll}
\hline Null Hypothesis: & Obs & F-Statistic & Prob. \\
\hline CM does not Granger Cause MO & 26 & 0.56567 & 0.4596 \\
MO does not Granger Cause CM & & 1.76654 & 0.1968 \\
X does not Granger Cause MO & 26 & $(5.44921)^{*}$ & 0.0287 \\
MO does not Granger Cause X & & $(4.29445)^{*}$ & 0.0496 \\
NFA does not Granger Cause MO & 26 & $(6.29883)^{*}$ & 0.0196 \\
MO does not Granger Cause NFA & & 1.78368 & 0.1948 \\
X does not Granger Cause CM & 26 & 1.53272 & 0.2282 \\
CM does not Granger Cause X & & 0.73169 & 0.4012 \\
NFA does not Granger Cause CM & 26 & 0.6777 & 0.4188 \\
CM does not Granger Cause NFA & & 2.41314 & 0.134 \\
NFA does not Granger Cause X & 26 & 1.91998 & 0.1791 \\
X does not Granger Cause NFA & & 4.34246 & 0.0485 \\
\hline
\end{tabular}

Note: * denotes significant at 5 percent.

The results reported in table $6 \mathrm{~b}$ show that at 5 percent critical value for F-Statistic, the null hypothesis that there is no causality between capital movement and money supply, export and capital movement, also between net foreign asset and capital movement is not rejected meaning that there is zero causality in each of these pairs. However, bidirectional causality is noticed in the relationship between export and money supply while unidirectional effect is evident in the relationship between net foreign asset and money supply, also between export and net foreign asset.

\section{Conclusion}

The study provides insights on the relationships among various components of money supply, export, import and national income and some components of money supply such as net domestic credit; while pars of variables such as net foreign asset and national income, net domestic credit and net foreign asset display long-run unidirectional causality. It is equally discovered that the marginal propensity to import is about 21 percent but the positive effects of this are underscored by the illegal or illicit activities of smugglers. The speed at which money circulates in Nigeria is approximately approaching 300 percent. Therefore, as the monetarists would say the economy of Nigeria is under the influence of inflation, and any creation of money without commeasurable economic/productive activities will further trigger/fuel the ember of inflation.

\section{Recommendations}

Based on our findings, we recommend that government should create and sustain more investment/economic activities instead of proposing the creation of new currency notes.

Also, the export base of the country should be diversified efficiently or optimally to allow investable funds to be directed to some other preferred sectors of the economy. Smuggling and importation of goods that can be produced locally should be prohibited, and the people involved should be sanctioned severely so that it will serve as deterrent to other. Also, productive minority should be strengthened through subsidies, incentives and other perquisites. Finally, the redenomination policy proposed by Soludo should be given a considerable attention.

\section{References}

Amin, S. B. (2011). Energy-growth nexus in Bangladesh: An empirical study. International Review of Business Research Papers, 2(2), 182-195.

Anoruo, E. (2002). Stability of the Nigerian M2 Money demand functions in the SAP Period. Economics Bulletin, 14, 1-9.

Bemanke, B. S., \& Blinder, A. S (1992). The federal funds rate and the channels of monetary transmission. American Economic Review, 82, 901-921.

Cagan, P. (1956). The monetary dynamic of hyperinflation. In M. Friedman (Ed.), Studies in the Quantity Theory of Money. Chigao: University of Chicago Press.

De Melo, J., \& Tybout, J. (1986). The effect of financial liberalization on saving and investment in Uruguay. Economic Development and Cultural Change, 34(3), 25-33. http://dx.doi.org/10.1086/451549 
Dickey, D. A., \& Fuller, W. A. (1979). Distribution of estimators for time series regressions with a unit root. Journal of the American Statistical Association, 74, 427-431.

Duck, N. (1993). Some international evidence on the Quantity Theory of Money. Journal of Money, Credit, and Banking, 25, 1-12. http://dx.doi.org/10.2307/2077816

Emenuga, C. (1996). The outcome of financial sector reform in West Africa. International Development Centre: Science for Humanity. Chapter 14.

Emerson, J. (2006). The Quantity Theory of Money: Evidence from the United States. Economics Bulletin, 5 , $1-6$.

Fry, M. J. (1997). In favour of financial liberalization. Economic Journal, 107, 754-770. http://dx.doi.org/10.1111/j.1468-0297.1997.tb00041.x

Ghatak, S. (1995). Monetary economic in developing countries (2nd ed.). New York: St. Martins.

Greenwood, J., \& Jovanovic, B. (1990). Financial reform: Theory and experience. University of Western Ontario Caprior.

Gujarati, D. N. (2003). Basic econometrics (4th ed.). New Delhi: Tata McGraw-Hill Publishing Company Ltd.

Johansen, S., \& Juselius, K. (1990). Maximum likelihood estimation and inference on cointegration with applications to the demand for money. Oxford Bulletin of Economics and Statistics, 52, 169-210. http://dx.doi.org/10.1111/j.1468-0084.1990.mp52002003.x

Karfakis, C. (2002). Testing the Quantity Theory of Money in Greece. Applied Economics, 34, 583-587. http://dx.doi.org/10.1080/00036840110070014

Mansor, A. (2005). Monetary policy and sectoral effect: A case study of Malaysia. Web Page Publication.

Miyao, R. (1996). Does a cointegrating $\mathrm{m} 2$ demand relation really exist in the United States? Journal of Money, Credit, and Banking, 28(3), 365-380. http://dx.doi.org/10.2307/2077980

Moazzami, B., \& Gupta, K. L. (1996). The Quantity Theory of Money and its long-run implications. Journal of Macroeconomics, 17, 667-682. http://dx.doi.org/10.1016/0164-0704(95)80088-3

Montiel, P. J. (1995). Financial policies and economic growth: Theory, evidence and country specific experience, from Sub-Saharan Africa. AERC Special Paper, 18.

Moosa, I. A. (1997). Testing the long-run neutrality of money in a developing economy: The case of India. Journal of Developmental Economics, 53, 139-155. http://dx.doi.org/10.1016/S0304-3878(97)00006-0

Nwafor, F. (2007). The Quantity Theory of Money in a developing economy: Empirical evidence from Nigeria. African Economic and Business Review, 5(1), 1-9.

Nwaobi, G. (2002). A vector error correction and nonnested modeling of money demand function in Nigeria. Economics Bulletin, 3, 1-8.

Omanukwue, P. N. (2010). The Quantity Theory of Money: Evidence from Nigeria Central Bank of Nigeria. Economic and Financial Review, 48(2).

Owoye, O., \& Onafowora, A. O. (2007). M2 targeting, money demand and real GDP growth in Nigeria: Do rules apply? Journal of Business and Public Affair, 1(2), 25-34.

Polak, J. J. (1957). Monetary analysis of income formation and payments problems. Staff Papers, 6(1), 1-50. IMF.

Polak, J. J. (1997a). The IMF monetary model, a hardy perennial. Finance and Development, IMF.

Polak, J. J. (1997b). The IMF monetary model at forty. Working Paper, IMF.

Polak, J. J., \& Argy, V. (1971). Credit policy and the balance of payments. Staff Papers, 16(1), 1-24. IMF. http://dx.doi.org/10.2307/3866373

Sen, H. (1999). The IMF and world bank approaches to macroeconomic management in developing countries. Journal of Economics \& Administrative Sciences, 5, 367-378.

Sims, C. A. (1992). Money income, causality American. Economic Review, 62, 540-542.

Wachtel, P., \& Raisseau, P. L. (1995). Financial intermediation and economic growth: A historical comparison of the U.S.A and Canada in Anglo-American finance. Journal of International Money and Finance, 21(6), 777-793. 


\section{Copyrights}

Copyright for this article is retained by the author(s), with first publication rights granted to the journal.

This is an open-access article distributed under the terms and conditions of the Creative Commons Attribution license (http://creativecommons.org/licenses/by/3.0/). 